\title{
Herbaceous biomass yield in the saline soils during the dry and rainy seasons in the municipality of Pentecoste, CE, Brazil
}

\section{Francisco Yago Elias de Castro Dias ${ }^{1 *}$ (I) Oriel Herrera Bonilla ${ }^{2}$ Eliseu Marlônio Pereira de Lucena ${ }^{2}$ Claudivan Ferreira de Lacerda ${ }^{3}$ Daniel Pereira de Oliveira ${ }^{4}$ Davi Rodrigues Oliveira ${ }^{3}$}

'Programa de Pós-graduação em Ecologia e Recursos Naturais (PPGERN), Centro de Ciências, Universidade Federal do Ceará (UFC), 60440-900, Fortaleza, CE, Brasil. E-mail: yagocastro2602@hotmail.com. "Corresponding author.

${ }^{2}$ Curso de Ciências Biológicas, Universidade Estadual do Ceará (UECE), Campus do Itaperi, Fortaleza, CE, Brasil.

${ }^{3}$ Departamento de Engenharia Agrícola (DENA), Centro de Ciências Agrárias, Universidade Federal do Ceará (UFC), Fortaleza, CE, Brasil. ${ }^{4}$ Curso de Química, Universidade Estadual do Ceará (UECE), Campus do Itaperi, Fortaleza, CE, Brasil.

ABSTRACT: This study was an endeavor undertaken to assess the biomass yield of the species that are native to a particular region characterized by saline soil, in the Irrigated Perimeter Curu-Pentecoste, in the municipality of Pentecoste-CE, corresponding to the qualities of moisture, pH and electrical conductivity (EC) of the soil. The experiment was conducted in six areas, with area 1, the one nearest to the collecting drain, the end having the highest salinity and area 6, the one furthest away from the collecting drain, the end with the lowest salinity. The factorial design with the $2 \times 6$ scheme was adopted, in which the first and second factors referred, respectively, to the seasons (drought and rain collection) and collection areas. In each area, eight permanent $5 \times 5 \mathrm{~m}$ plots were demarcated, which included 8 repetitions per treatment. Within each permanent plot the quantity of forage was gathered within an area of $0.25 \times 0.25 \mathrm{~m}$. Soil samples were taken from a depth of $0-20 \mathrm{~cm}$, and the EC, pH and soil moisture were determined. The phytomass was oven dried, after which the water content and yield were recorded. Three subsamples per area were burned in a muffle furnace to determine the percentage of ash content. The resultant high $\mathrm{pH}$ and EC values, typical of arid soils and related to the significantly low humidity, can cause harm to most of the crops cultivated in the Northeast of Brazil. However, the biomass yield was substantial, indicating that the species occurring there possessed adaptive mechanisms to enable them to tolerate the conditions of saline soil and water stresses prevalent there.

Key words: phytomass, halophytes, salinization.

Rendimento da biomassa herbácea em solos salinos nas estações seca e chuvosa no município de Pentecoste, CE, Brasil

RESUMO: $O$ objetivo do trabalho foi avaliar o rendimento de biomassa vegetal de espécies presentes naturalmente em uma área com o solo salinizado no perímetro irrigado Curu-Pentecoste, no município de Pentecoste, CE, correlacionando com os atributos umidade, pH e condutividade elétrica (CE) do solo. O experimento foi realizado em 6 áreas, sendo a área 1 mais próxima do dreno coletor o extremo mais salinizado, e a área 6 mais distante do dreno coletor, o extremo menos salinizado. Utilizamos do delineamento fatorial no esquema $2 \times 6$, com primeiro fator referente às estações de coleta (seca e chuva), e o segundo relativo às áreas. Foram marcadas em cada uma das áreas 8 parcelas permanentes de $5 \times 5 \mathrm{~m}$ e em cada parcela permanente foram realizadas coletas da porção forrageira dentro de um quadrado de 0,25 $\times 0,25$ m. Amostras de solo de 0-20 cm de profundidade foram coletadas para a obtenção da CE, do pH e da umidade do solo. A fitomassa foi secada em estufa, onde foram mensurados o seu conteúdo de água e biomassa seca. Três subamostras por área foram queimadas em mufla para a obtenção do seu conteúdo de cinzas. O pH e CE elevados do solo mostraram características típicas de solos de clima árido, que associados a uma significante diminuição da umidade desse, podem causar prejuizos na maioria dos cultivos no Nordeste brasileiro. Entretanto, o rendimento de biomassa foi elevado, o que demonstra que as espécies ali presentes possuem mecanismos adaptativos para tolerância aos estresses salino e hídrico.

Palavras-chave: fitomassa, halófitas, salinização.

\section{INTRODUCTION}

Among the principal abiotic stresses, salinity ranks high in causing soil degradation, negatively affecting agricultural yield, particularly in the arid and semi-arid areas (RIBEIRO et al., 2016). On the contrary, the projected rise in the world population over the next few decades makes the cultivation of halophytic plants, which included those species that can accomplish their whole life cycle in regions of high soil salinity, a significant achievement for sustainable agriculture. (PANDOLFI et al., 2012). In light of this fact, many of the halophyte species native to the northeastern regions in Brazil with the highly saline soils possess high food potential, such as Blutaparon vermiculare (L.) Mears (MEDEIROS; 
ALBUQUERQUE, 2014), Sesuvium portulacastrum (L.) L. (MEDINA et al., 2008; LOCKANDE et al., 2009), Salicornia bigelovii Torr. (ZERAI et al., 2010), and Sarcocornia ambigua (Michx.) Alonso \& Crespo (PINHEIRO et al., 2017); however, this immense potential has not been exploited at all in Brazilian cooking (COSTA; HERRERA, 2016).

Although, they have not yet been capitalized upon, to great degree, the plant biomass produced through halophyte cultivation offers several benefits. It can be utilized as human food, cattle feed / fodder and in the manufacture of bioactive products. These plants can also find use in the phytoremediation projects to counter the anthropogenic impacts unleashed upon coastal environments including marshes, mangroves and coastal dunes (COSTA \& HERRERA, 2016).

Research done earlier on assessing the plant biomass yield from the cultivation of halophytic crops have shown promise. In their study, PINHEIRO et al., (2017) estimated the output of the halophyte Sarcornia ambigua with effluents from shrimp farms. They reported satisfactory findings from raising this halophyte hydroponically in association with the production of Litopenaeus vannamei, a species of shrimp. In their research, MELO et al., (2016) studied the harvest of the Atriplex nummularia under unfavorable conditions of salt and water stresses, where the biomass produced escalated proportional to the rise in the electrical conductivity in the irrigation water used.

From this perspective, the hypothesis proposed in this study implies that plant biomass produced in the saline soils is identical to the yield from the regions with non-saline soil, during the dry and rainy seasons, because the species native to these habitats must possess adaptive mechanisms that support their growth under unfavorable conditions. This research aimed to assess the plant biomass produced and ash content of the native species occurring in the regions possessing soils ranging from low salt soil to highly saline soil, within the Irrigated Perimeter, present in a seasonally dry location, relating these to the variables of moisture, $\mathrm{pH}$ and electrical conductivity of the soil. Thus, the objective of this study was to provide data through an in situ analysis, which can be used as a subsidy for the exploitation of the unused deserted regions because of such environmental stresses.

\section{MATERIALS AND METHODS}

The study extended from May / 2016 to March / 2017, and the samples were gathered during the seasons of rain (February to May) and dry weather (June to January), within the core D region of the Irrigated Perimeter Curu-Pentecoste, in the municipality of Pentecoste-CE $\left(03^{\circ} 48^{\prime} 04.3^{\prime \prime} \mathrm{S} 39^{\circ}\right.$ $18^{\prime} 11.3$ " W). The climate in this region, based on the Köppen classification, is BSw'h' type, semiarid, with the characteristic hot weather and low precipitation mainly from January to April. With $860 \mathrm{~mm}$ average annual rainfall and $1,474 \mathrm{~mm}$ average annual evaporation a significant water deficit was evident. The average annual temperature hovers around $27^{\circ}$ $\mathrm{C}$ and average relative air humidity is about $73.7 \%$ (BEZERRA, 2006).

The perimeter contains the typical Neossolo Fluvic soil type, because it lies in the alluvial lowland areas. The water is supplied from the General

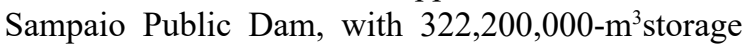
capacity and the Public Pereira de Miranda Dam, with $395,638,000-\mathrm{m}^{3}$ storage capacity. The major irrigation system of the Perimeter is made in the furrows on the surface, while drainage occurs through the open drains, the main collection rivers being the Curu and Canindé (BEZERRA, 2006).

Using a piece of abandoned land for agricultural cultivation, the field experiments were conducted. The area closest to the collecting drain of the irrigation system was characterized by highly saline soil (Area 1), and moving away from the collecting drain, five more areas were marked out (Areas 2 to 6), each roughly $20 \mathrm{~m}$ long. Eight permanent plots $5 \times 5 \mathrm{~m}$ in area were demarcated in each area, and the entire herbaceous plant biomass was harvested at ground level within the area of $25 \times 25 \mathrm{~cm}$. All the samples were gathered during October (the month with the least rainfall in 2016) and March (the peak of the rainy season in 2017), thus representing the samples of the dry and the rainy seasons, respectively.

At four points of the square from where the biomass was gathered, the soil samples were drawn from $0-20 \mathrm{~cm}$ depth using a hand auger. They were then mixed to represent a sample according to each plot. Some of the soil sample portions were stored in plastic bags with suitable identifications and some amount was stored in $200 \mathrm{ml}$ metal pots and hermetically sealed. Table 1 shows the characteristics of the soil from each area.

The weight of the soil samples in the metal pots was measured on an analytical balance and their wet weight was recorded. The samples were then placed in a forced aeration oven at $65^{\circ} \mathrm{C}$ for drying, until constant weight was achieved. Post drying, the samples were weighed once more and the dry weight was noted. 
Table 1 - Soil chemical analysis of the regions located in the experimental area in the Irrigated Perimeter Curu-Pentecoste. Mean \pm standard deviation.

\begin{tabular}{|c|c|c|c|c|c|c|}
\hline \multirow{2}{*}{ Areas } & \multicolumn{4}{|c|}{ 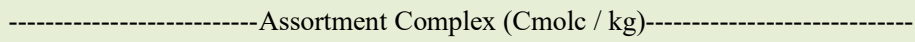 } & $(\mathrm{g} / \mathrm{kg})$ & $(\mathrm{mg} / \mathrm{kg})$ \\
\hline & $\mathrm{Ca}$ & $\mathrm{Mg}$ & $\mathrm{Na}$ & $\mathrm{K}$ & $\mathrm{N}$ & $\mathrm{P}$ \\
\hline 1 & $2.90 \pm 1.08$ & $1.70 \pm 0.36$ & $37.86 \pm 3.18$ & $0.35 \pm 0.05$ & $0.80 \pm 0.08$ & $13.33 \pm 4.04$ \\
\hline 2 & $3.90 \pm 0.57$ & $3.90 \pm 0.85$ & $19.08 \pm 0.93$ & $0.36 \pm 0.02$ & $0.87 \pm 0.16$ & $14.50 \pm 3.54$ \\
\hline 3 & $9.35 \pm 3.61$ & $8.50 \pm 1.56$ & $7.67 \pm 0.67$ & $0.49 \pm 0.01$ & $1.93 \pm 0.14$ & $7.50 \pm 2.12$ \\
\hline 4 & $12.25 \pm 0.92$ & $8.95 \pm 1.34$ & $4.55 \pm 0.22$ & $0.60 \pm 0.18$ & $1.80 \pm 0.39$ & $8.00 \pm 1.41$ \\
\hline 5 & $9.55 \pm 0.64$ & $7.40 \pm 0.57$ & $4.65 \pm 2.26$ & $0.58 \pm 0.10$ & $1.86 \pm 0.09$ & $12.50 \pm 10.61$ \\
\hline 6 & $6.20 \pm 1.84$ & $4.15 \pm 2.62$ & $0.90 \pm 0.79$ & $0.33 \pm 0.05$ & $1.26 \pm 0.23$ & $6.00 \pm 1.41$ \\
\hline
\end{tabular}

The samples in each of the plastic bags were air dried, powdered and passed through a 2 $\mathrm{mm}$ sieve. Later, the samples diluted with distilled water were tested for electrical conductivity (soil salinization proxy) and $\mathrm{pH}$ analyses. For electrical conductivity, 1:1 dilution and decantation were done over a 24-h period, and for $\mathrm{pH}$ 1:2.5 dilution and 1-h decantation period.

Initially, the biomasses were weighed using an analytical balance and their fresh weight was noted. Next, they were oven-dried in a forced aeration oven at $65^{\circ} \mathrm{C}$ until constant weight was attained, and their dry weight was recorded. Using these values, the dry biomass yield was calculated employing the formula:

$$
Y=\frac{S D W}{A}
$$

Where:

Y - yield (kg.ha-1)

SDW - sample dry weight $(\mathrm{kg})$

A - sampled area (ha)

The water content was also calculated relative to the fresh weight, using the formula (MEDINA et al., 2008):

$$
\mathrm{SWC}=\frac{\mathrm{FW}-\mathrm{SDW}}{\mathrm{FW}}
$$

Where:

SWC - water content (\%)

Fw - fresh sample weight $(\mathrm{kg})$

SDW - weight with your friend $(\mathrm{kg})$

In each area, three dry matter subsamples of $1 \mathrm{~g}$ each, were burned in a muffle furnace at $550^{\circ} \mathrm{C}$ and the ashes were obtained. We calculated the ash content based on the formula given (MEDINA et al., 2008):

$$
\mathrm{AC}=\frac{\mathrm{AW}}{\mathrm{TDW}} * 100
$$

Where:

AC - ash content $(\%)$

AW - ashes (g)

TDw - dry matter subsample weight $(\mathrm{g})$

The factorial design with the $2 \times 6$ scheme was adopted, where the first factor involved both collection seasons (drought and rain) and the second included the areas (areas 1 to 6), to account for a total of 12 treatments. Each treatment comprised eight repetitions, relating to the permanent plots demarcated in each area, barring the ash content treatment, for which three repetitions were done with reference to the subsamples. The Shapiro-Wilk test was used to analyze the normality of the data. The analysis of variance (ANOVA) was performed with a $5 \% \mathrm{~F}$ test, after which the means were compared by the Tukey test, to identify the likely variations in the values of soil moisture, electrical conductivity and $\mathrm{pH}$, as well as in the dry biomass yield, water content and ash content of the plant biomass samples. In the absence of any variations between the factors, the influence exerted by the factors alone was assessed.

To estimate the relationship existing between the qualities of the soil and yield of the dry plant biomass, ash and water contents, Pearson's linear correlation analysis was employed. All the statistical analyses were performed using the BioEstat 5.0 program (AYRES et al., 2007).

\section{RESULTS AND DISCUSSION}

The species listed were identified, with their relative frequencies (frequencies above 5\%), when they were gathered during the rainy season: Blutaparon vermiculare (L.) Mears (20.98\%), Cyperus rotundus L. (11.89\%), Malachra fasciata Jacq. (8.39\%), Sesuvium portulacastrum (L.) L. (8.39\%), Physalis angulata L. (7.69\%), Paspalum 
ligulare Nees (6.99\%), Sesbania exasperata Kunth. (6.29\%), Ipomoea asarifolia (Desr.) Roem. \& Schult. (5.59\%) and Sida rhombifolia L. (5.59\%); and those gathered during the dry season included, Blutaparon vermiculare (L.) Mears (52.46\%), Cyperus rotundus L. (16.39\%), Sesuvium portulacastrum (L.) L. (9.84\%), Ipomoea asarifolia (Desr.) Roem. \& Schult. (6.56\%) and Malachra fasciata Jacq. (6.56\%).

For both the collection stations, area 1, the one nearest to the collecting drain and the first to be established as having the highest salinity, revealed the highest values of electrical conductivity of the soil, with area 2 being the second (Figure 1A). During the dry season, no difference was evident in the values of soil electrical conductivity between areas 4 and 5 , while during the same season the values of areas 3 and 4 was distinctly higher $(\mathrm{p}<0.001)$ than those of areas 5 and 6 . When considering the soil $\mathrm{pH}$ (Figure 1B), the values showed no variation between the treatments and between the collection stations, the only exception being area 1 , which revealed a lower $\mathrm{pH}$ value. The treatments during the rainy season, in all the areas, showed higher values for soil moisture (Figure 1C), but no variations were noted between treatments in the dry season. The high values identified for the $\mathrm{pH}$ and electrical conductivity were close to the characteristic values reported for arid regions (FERNÁNDEZ et al., 2016).

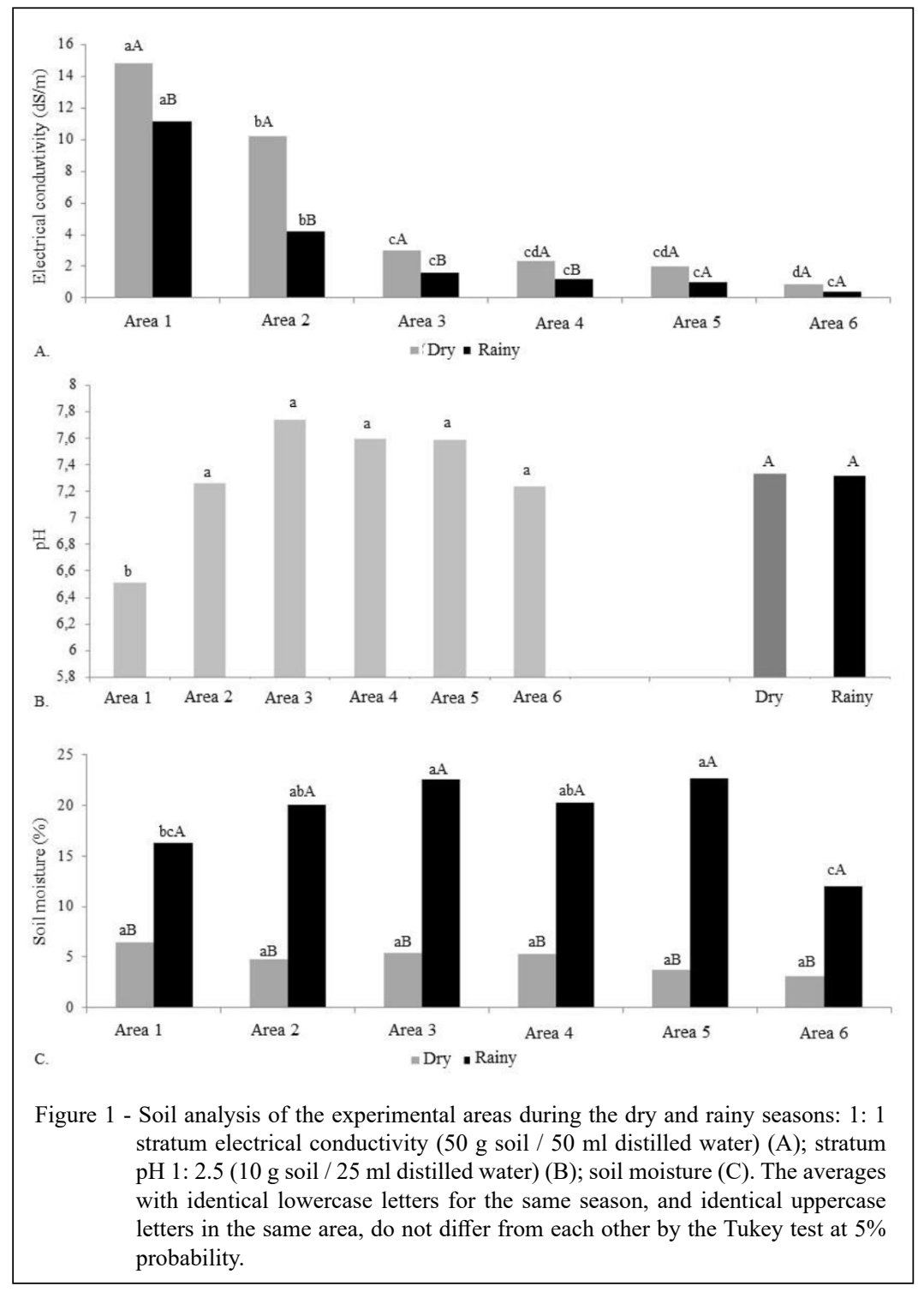

Ciência Rural, v.50, n.3, 2020. 
In such conditions, for both seasons, the electrical conductivity of the soil may induce a lowered yield for most of the crops cultivated in the northeastern backlands (BEZERRA, 2006), because of the reduced osmotic potential, heightened ionic toxicity and imbalance in the absorption of water and nutrients (LIMA-NETO et al., 2015). However, for the halophytic species, MANOUSAKI \& KALOGERAKIS (2009) a high tolerance for the soils with values of electrical conductivity in the 10-12 dS.m-1 range was evident, without their development being affected.

During the dry season, compared to the rainy season, the rise in the electrical conductivity of the soil observed can be understood because of the decline in the soil moisture, because it mirrors the water deficit occurring in the region, which becomes more noticeable at this point in time. Water deficit produces efficient natural leaching, dilution and dissolution which, when related to the rise of the salts through capillary action induced by the high rates of evaporation, liberate an accumulation of ions in the surface layer of the soil horizons (RIBEIRO et al., 2016; ZERAI et al., 2010).

During the rainy season, the treatments in all the areas revealed higher dry biomass yields (Figure 2A) compared to their dry season values. During the dry season; however, areas 2 and 3 showed the highest dry biomass yield values, while areas 5 and 6 revealed the lowest values. Areas 1

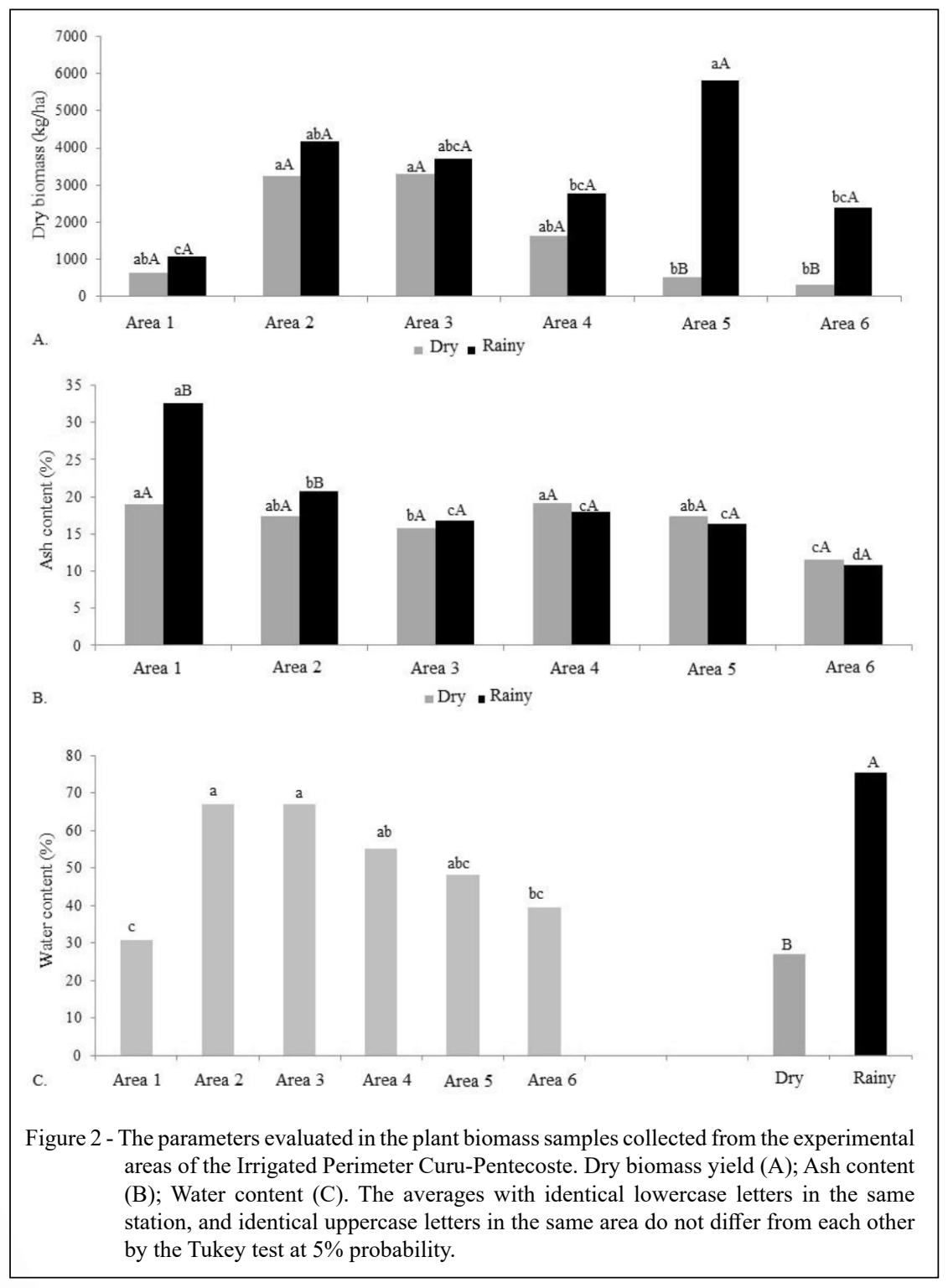

Ciência Rural, v.50, n.3, 2020. 
and 2 showed a boost in the ash content (Figure 2B) in the treatments during the dry season, which was not, observed for the rainy season treatments, but no significant variations were noted in the other areas. During the rainy season, the treatment in area 6 revealed the lowest ash content values, while during the dry season, the treatment in this area registered the second lowest values, together with the treatments in the areas 3, 4 and 5 during the dry season. The escalation in the ash contents of the areas 1 and 2 during the dry season over those from the rainy season, were contrary to the values of the electrical conductivity in these areas, which revealed a decline during the same period. This could be attributed to the rise in the soil salinity, which triggered higher ion absorption (Davenport, 2008).

The high frequency of occurrence of the halophytic species in the areas 1, 2, 3, 4 and 5, which included the species Blutaparon vermiculare (L.) Mears and Sesuvium portulacastrum (L.) L. account for the plant biomass and ash content yields, because the halophyte species possess mechanisms for salinity tolerance that enable them to grow and develop even under unfavorable conditions of high ionic concentrations, and they have the capacity to store these salts within their tissues (BARROSO et al., 2006; FLOWERS \& COLMER, 2008). However, it is striking that for particular animal crops, like those for goats and sheep, the salt content in the feed is limited to $10 \mathrm{~g}$ of salt per $100 \mathrm{~g}$ of dry matter. This limit restricts the usage of halophytic crops as fodder, suggesting that it will be better to mix them with other food sources (MIYAMOTO et al., 1994).
The water content (Figure 2C) of the biomass sampled showed higher values during the rainy season, in fact more than $70 \%$, a reading regarded as high for the non-halophytic plant species, which is indicative of significant adaptive response in the halophyte species (GARCÍA et al., 2008; MEDINA et al., 2008).

The water content during the dry season showed a strong correspondence to the ash content (Table 2), suggesting an inclination for the biomasses having higher water content to also possess a higher ash content, and these parameters could be physiologically consistent with the internal control of ion concentration (MEDINA et al., 2008). In these halophytic plants, the rise in the water content facilitates a boost in the ability of the plant to store salts within its vacuoles, thus enabling osmotic adjustments that can safeguard the plant from the toxic influence of surplus salt (WYNJONES \& GORHAM, 2002).

The dry biomass yield and water content revealed no correlation with any of the soil qualities, in any of the collection stations. The ash content; however, during the rainy season, revealed a strong positive correlation with the soil electrical conductivity (Table 2). The halophytic species have the ability to adapt through compartmentalization and intracellular excretion of sodium, as well as through the generation and storage of organic solutes (FLOWERS \& COLMER, 2015; FLOWERS et al., 2010; ROZEMA \& SCHAT, 2013), which could possibly throw some light upon the rise in the ash content in response to the increased electrical conductivity of the soil.

Table 2 - Pearson linear correlation matrices between the dry biomass yield, ash content and soil attributes (electrical conductivity, pH and moisture) during the dry and rainy seasons in the Irrigated Perimeter Curu-Pentecoste.

\begin{tabular}{|c|c|c|c|c|c|}
\hline Variables & $\mathrm{AC}$ & $\mathrm{CC}$ & $\mathrm{EC}$ & $\mathrm{pH}$ & $\mathrm{U}$ \\
\hline \multicolumn{6}{|l|}{ Dry season } \\
\hline Biomass yield (PB) & $0.3752^{\mathrm{ns}}$ & $0.1686^{\mathrm{ns}}$ & $0.1124^{\mathrm{ns}}$ & $0.4099^{\text {ns }}$ & $0.3367^{\text {ns }}$ \\
\hline Water content (AC) & - & $0.9694 *$ & $0.4834^{\mathrm{ns}}$ & $0.0836^{\mathrm{ns}}$ & $0.8010^{\mathrm{ns}}$ \\
\hline Ash content (CC) & - & - & $0.5063^{\mathrm{ns}}$ & $-0.0349^{\mathrm{ns}}$ & $0.7195^{\text {ns }}$ \\
\hline Electrical conductivity (EC) & - & - & - & $-0.7593^{\mathrm{ns}}$ & $0.6913^{\text {ns }}$ \\
\hline $\mathrm{pH}$ & - & - & - & - & $-0.2243^{\mathrm{ns}}$ \\
\hline \multicolumn{6}{|l|}{ Rainy season } \\
\hline Biomass Production (PB) & $0.2395^{\mathrm{ns}}$ & $-0.4691^{\mathrm{ns}}$ & $-0.5749^{\mathrm{ns}}$ & $0.6420^{\text {ns }}$ & $0.4568^{\text {ns }}$ \\
\hline Water content (AC) & - & $-0.4555^{\text {ns }}$ & $-0.4849^{\text {ns }}$ & $0.5856^{\mathrm{ns}}$ & $0.5757^{\text {ns }}$ \\
\hline Ash content $(\mathrm{CC})$ & - & - & $0.9643^{*}$ & $0.6283^{\text {ns }}$ & $0.0581^{\mathrm{ns}}$ \\
\hline Electrical conductivity (EC) & - & - & - & $-0.7853^{\mathrm{ns}}$ & $-0.1484^{\mathrm{ns}}$ \\
\hline $\mathrm{pH}$ & - & - & - & - & $0.6854^{\mathrm{ns}}$ \\
\hline
\end{tabular}

*Significant at 5\% probability; ns - Nonsignificant; U - soil moisture. 


\section{CONCLUSION}

The conclusion drawn was that the plant biomass yield was similar, irrespective of whether the soil was high in salinity or otherwise. The yield showed no variation along the dry and rainy seasons. With respect to the ash content, further studies are necessary to determine the use of these halophytes in animal fodder.

\section{ACKNOWLEDGEMENTS}

We thank the Cearense Foundation of Support for Scientific and Technological Development of the State of Ceará (FUNCAP) for the grant to F.Y.E.C. Dias. This study was financed in part by the Coordenação de Aperfeiçoamento de Pessoal de Nível Superior (CAPES), Brasil - Finance code 001. We also thank the staff of the Curu Valley Experimental Farm for local support.

\section{DECLARATION OF CONFLICT OF INTERESTS}

The authors declare no conflict of interest. The founding sponsors had no role in the design of the study; in the collection, analyses, or interpretation of data; in the writing of the manuscript, and in the decision to publish the results.

\section{AUTHORS' CONTRIBUTIONS}

FYECD, OHB, EMPL and CFL designed the study. FYECD, OHB, CFL, DRO and DPO performed the experiments. FYECD, OHB and EMPL performed statistical analyses of experimental data. FYECD, OHB, EMPL and CFL analyzed the data. All the authors contributed to the writing of the manuscript and approved of the final version.

\section{REFERENCES}

AYRES, M. et al. BioEstat 5.0: aplicações estatísticas nas áreas das ciências biológicas e médicas. 5. ed. Belém: Instituto de Desenvolvimento Sustentável Mamirauá, 2007. 365p.

BARROSO, D. D. et al. Productivity and nutritive value of different forage fractions of saltbush (Atriplex nummularia) irrigated with four different volumes of effluent from tilapia raised on brackish water. Agropecuária Técnica, v.27, n.1, p.43-48, 2006. Available from: <https://www.alice.cnptia.embrapa.br/alice/bitstream/ doc/158499/1/OPB1017.pdf >. Accessed: May, 20, 2018. doi: $10.1590 / \mathrm{S} 1415-43662006000100015$

BEZERRA, E. A salinização de solos aluviais em perímetros irrigados no estado do Ceará. Série ConViver, 2. Fortaleza: DNOCS, 2006. 136p.

COSTA, C. S. B.; HERRERA, O. B. Halófitas brasileiras: Formas de cultivo e usos. In: GHEYI, H. R. et al. Manejo da salinidade na agricultura: Estudos básicos e aplicados. Fortaleza: INCTSal, 2016. Cap.16, p.223-258.

FERNÁNDEZ, Y. T. et al. Phytoestabilization of arsenic in soils with plants of the genus Atriplex established in situ in the Atacama desert. Environmental Monitoring and Assessment, v.188, n.4, p.188-235, 2016. Available from: <http://dx.doi.org/10.1007/ s10661-016-5247-x>. Accessed: Nov. 13, 2018. doi: 10.1007/ s10661-016-5247-x.

FLOWERS, T. J.; COLMER, T. D. Salinity tolerance in halophytes. Journal of Experimental Botany, v.179, p.945-963, 2008. Available from: <https://doi.org/10.1111 /j.1469-8137.2008.02531.x>. Accessed: Jul. 17, 2018. doi: 10.1111/j.1469-8137.2008.02531.x.

FLOWERS, T. J.; COLMER, T. D. Plant salt tolerance: adaptations in halophytes. Annals of Botany, v.115, p.327-331, 2015. Available from: $<$ https://doi.org/10.1093/aob/mcu267>. Accessed: Jul. 17, 2018. doi: 10.1093/aob/mcu267.

FLOWERS, T. J. et al. Evolution of halophytes multiple origins of salt tolerance in land plants. Functional Plant Biology, v.37, p.604-612, 2010. Available from: <https://doi.org/10.1071/ FP09269>. Accessed: jul. 17, 2018. doi: 10.1071/FP09269.

GARCÍA, M. et al. Adaptaciones anatómicas foliares en especies de angiospermas que crecen en la zona costera del estado Falcon (Venezuela). Acta Botánica Venezuela, v.31, n.1, p.291-306, 2008. Available from: $<$ http://ve.scielo.org/scielo.php?script $=$ sci arttext\&pid $=$ S008459062008000100010\&lng $=$ es\&nrm $=$ iso $>$. Accessed: Jan. 26, 2018.

LIMA-NETO, A. J. et al. Mudas de tamarindeiro irrigadas com água salina em solo sem e com biofertilizantes. Irriga, v.20, n.4, p.730-744, 2015. Available from: <http://dx.doi.org/10.15809/ irriga.2015v20n4p730>. Accessed: mar. 26, 2017. doi: 10.15809/ irriga.2015v20n4p730.

LOKHANDE, V. H. et al. Sesuvium portulacastrum L. a promising halophyte: Cultivation, utilization and distribution in India. Genetic Resource and Crop Evolution, v.56, p.741-747, 2009. Available from: <https://link.springer.com/article/10.1007/s10722-009-94351>. Accessed: Feb. 26, 2018. doi: 10.1007/s10722-009-9435-1.

MANOUSAKI, E.; KALOGERAKIS, N. Phytoextraction of $\mathrm{Pb}$ and $\mathrm{Cd}$ by the Mediterranean saltbush (Atriplex halimus L.) metal uptake in relation to salinity. Environmental Science and Pollution Research, v.16, p.844-854, 2009. Available from: $<$ https://doi.org/10.1007/s11356-009-0224-3>. Accessed: Nov. 29, 2018. doi: 10.1007/s11356-009-0224-3.

MEDEIROS, M. F. T.; ALBUQUERQUE, U. P. Food flora in 17 th century northeast region of Brazil in Historia Naturalis Brasiliae. Journal of Ethnobiology and Ethnomedicine, [s.1.], v.10, n.1, p.10-50, 2014. Available from: <https://doi. org/10.1186/1746-4269-10-50>. Accessed: May, 02, 2018. doi: $10.1186 / 1746-4269-10-50$.

MEDINA, E. et al. Halofitismo en plantas de la costa Caribe de Venezuela: Halófitas y halotolerantes. Acta Botánica Venezuela, v.31, n.1, p.49-80, 2008. Available from: <https://www. researchgate.net/publication/262593952_Halofitismo_en_plantas_ de la costa caribe de Venezuela Halofitas y halotolerantes $>$. Accessed: jan. 26, 2018.

MELO, H. F. et al. Growth, biomass production and ions accumulation in Atriplex nummularia Lindl grown under abiotic stress. Revista Brasileira de Engenharia Agrícola e Ambiental, v.20, n.2, p.144-151, 2016. Available from: <http://dx.doi. org/10.1590/1807-1929/agriambi.v20n2p144-151>. Accessed: Mar. 03, 2019. doi: 10.1590/1807-1929/agriambi.v20n2p144-151.

Ciência Rural, v.50, n.3, 2020. 
MIYAMOTO, S. et al. Utilization of halophytic plants for fodder production with brackish water in subtropic deserts. In: SQUIRES, V. R.; AYOUB, A. T. Halophyte as a resource for livestock and for rehabilitation of degraded lands. Amsterdam: Kluwer Academic, 1994. p.43-75. Available from: <https://doi. org/10.1007/978-94-011-0818-8_5>. Accessed: May, 02, 2018. doi: 10.1007/978-94-011-0818-8_5.

PANDOLFI, C. et al. Physiology of acclimation to salinity stress in pea (Pisum sativum). Environmental and Experimental Botany, v.84, p.44-51, 2012. Available from: <https://doi.org/10.1016/j. envexpbot.2012.04.015>. Accessed: May, 02, 2018. doi: 10.1016/j. envexpbot.2012.04.015.

PINHEIRO, I. et al. Production of the halophyte Sarcocornia ambigua and Pacific white shrimp in an aquaponic system with biofloc technology. Ecological Engineering, v.100, p.261-267, 2017. Available from: <https://doi.org/10.1016/j. ecoleng.2016.12.024>. Accessed: May, 02, 2018. doi: 10.1016/j. ecoleng.2016.12.024.

RIBEIRO, M. R. et al. Origem e classificação dos solos afetados por sais. In: GHEYI, H. R. et al. Manejo da salinidade na agricultura: Estudos básicos e aplicados. Fortaleza: INCTSal, 2016. Cap.2, p.9-16.
ROZEMA, J.; SCHAT, H. Salt tolerance of halophytes, research questions reviewed in the perspective of saline agriculture. Environment and Experimental Botany, v.2, p.83-95, 2013. Available from: <https://doi.org/10.1016/j. envexpbot.2012.08.004>. Accessed: May, 02, 2018. doi: 10.1016/j. envexpbot.2012.08.004.

TESTER, M.; DAVENPORT, R. J. Na ${ }^{+}$transport and $\mathrm{Na}^{+}$tolerance in higher plants. Annals of Botany, v.91, p.503-527, 2008. Available from: $<$ https://doi.org/10.1093/aob/mcg058>. Accessed: Jul. 17, 2018. doi: 10.1093/aob/mcg058.

WYN-JONES, G.; GORHAM, J. Intra and inter cellular compartmentation of ions. In: LÄUCHLI, A.; LÜTTGE, U. Salinity: Environment-plants-molecules. Dordrecht: Kluwer Academic Publishers, 2002. p. 159-180. Available from: https:// link.springer.com/content/pdf/10.1007\%2F0-306-48155-3.pdf. Accessed: Dec. 19, 2017. doi: 10.1007/0-306-48155-3_8.

ZERAI, D. B. et al. Potential for the improvement of Salicornia bigelovii through selective bredding. Ecological Enginnering, v.36, p.730-739, 2010. Available from: <https://doi.org/10.1016/j. ecoleng.2010.01.002>. Accessed: Mar. 03, 2019. doi: 10.1016/j. ecoleng.2010.01.002. 